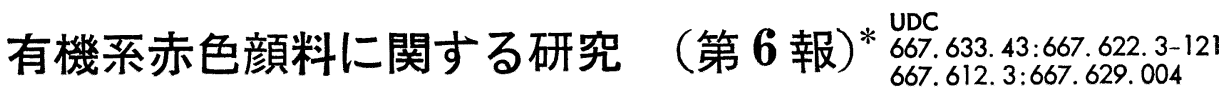

——塗 料の貯 蔵 性—

\section{Studies on red organic pigments VI}

Storage stability of paints

要旨

有機系赤色顔料の塗料貯蔵性研究の一環として, 諸添

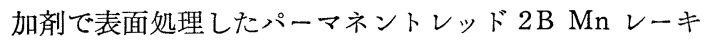
で着色したメラミン塗料の貯蔵性を検討し, 諸添加剤の 塗料貯蔵性に及ぼす影響を調べた。

\section{1. 実 験 方 法}

レーキ化前または後に諸添加剤を添加してつくったパ ーマネントレッド $2 \mathrm{~B}$ Mn レーキをメラミン塗料中に三 本ロールにより分散して, 得た着色メラミン塗料を室温 下 $\left(15 \sim 25^{\circ} \mathrm{C}\right)$ に放置貯蔵し, 貯蔵前後の塗料の粘度・ 色相・色分カレ・着色力, 顔料粒子の分散状態などを比 較検討した。

a. 供 試 試 料

i) 顔料 (パーマネントレッド $2 \mathrm{~B} \mathrm{Mn} \mathrm{レーキ)}$

顔料の製法は 2-クロル-4-アミノトルエン-5-スルホ ン酸と $\beta$ ーオキシナフトエ酸とを常法によりカップリン グし, 得た染料を水中に分散し， $50^{\circ} \mathrm{C}$ で $\mathrm{MnCl}_{2}$ を加 光， $100^{\circ} \mathrm{C}$ に加熱し口過水洗して $70 \sim 80^{\circ} \mathrm{C}$ で水分 $2 \%$ 以下になるまで乾燥する。諸添加剤のらちセッケン類は レーキ化前に添加し，その他は乾燥前の口過ケーキに添 加した。ヒマシ油・アルキド樹脂は乳化して添加した。

ii) 添 加 剂

顔料の表面処理に用いた諸添加剤はいずれも市販品を 用いた。

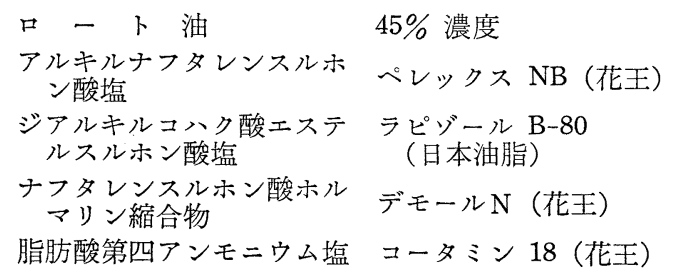

昭 35. 12. 5 受理

* 第 5 報 色材 30 [2]（1957）54 56

**冨士色素株式会社

$\overline{6[5]}$
中 嶋 直 一** ・兵 藤 誠 治**
NAKAZIMA Naoiti HYoDô Seizi

$$
\begin{aligned}
& \text { 脂肪アミン } \\
& \text { ピリジニウム塩 } \\
& \text { ポリオキシエチレン } \\
& \text { ラウリルエーテル } \\
& \text { " } \\
& \text { "オレイルエーテル } \\
& \text { （A）エマルゲン } 120 \text { (花王) } \\
& \text { （B）エマルゲン } 106 \text { (花王) } \\
& \text { ノイゲン ET } 80 \\
& \text { (第一工業) } \\
& \text { ベッコゾール } 1307 \text { (日本ライヒホールド) } \\
& \text { スーパーベッカミン J-820 (日本ライヒホールド) } \\
& \text { ブタノール・キシレン溶剤 } 50 \%
\end{aligned}
$$

b. 塗料調製 法

$$
\text { 原色塗 料 }
$$

パーマネントレッド $2 \mathrm{~B} \mathrm{Mn} \mathrm{レーキ} 10$ 部

大豆油変性アルキド樹脂

67.5 部

ブチル化メラミン樹脂 22.5 部

計 100 部

白 叙 料

\begin{tabular}{crc} 
ルチル形チタン白 & 20 & 部 \\
大豆油変性アルキド樹脂 & 60 & 部 \\
ブチル化メラミン樹脂 & 20 & 部 \\
\hline 計 & 100 & 部
\end{tabular}

上記の配合でそれぞれ三本ロールに6回通し希釈溶剂 （ブタノール：キシレン=1:9）を幾分追加し規定量と する。淡色塗料は原色塗料 1 部に対し, 白塗料 10 部を 混和してつくった。

\section{c. 貯 蔵性試 験 \\ i) 粘 度}

見掛けの粘度および系引き状態によって判定した。ほ 
とんど変化しないものを 0 ，増加したものを十とした。 また，わずかに増加したものを 1 ，やや増加を 2 ，著し いもの（ゲル化状態）を 3 とした。

ii) 色

カキマゼ混和した 塗料そのものの色と， $120^{\circ} \mathrm{C} 30$ 分
焼付けした塗面の色について判定した。両者の判定結果 にはほとんど差異はなかった。貯蔵前後の色の差がほと んぞないもの（0１ NBS）を0，わずか（1.1〜3 NBS） なものを 1 , ややあるもの (3.1〜6 NBS) を 2 , 著しい もの $>6.1 \mathrm{NBS})$ を 3 とした。また, 色相汇黄味に変化 表 1 実 験結果

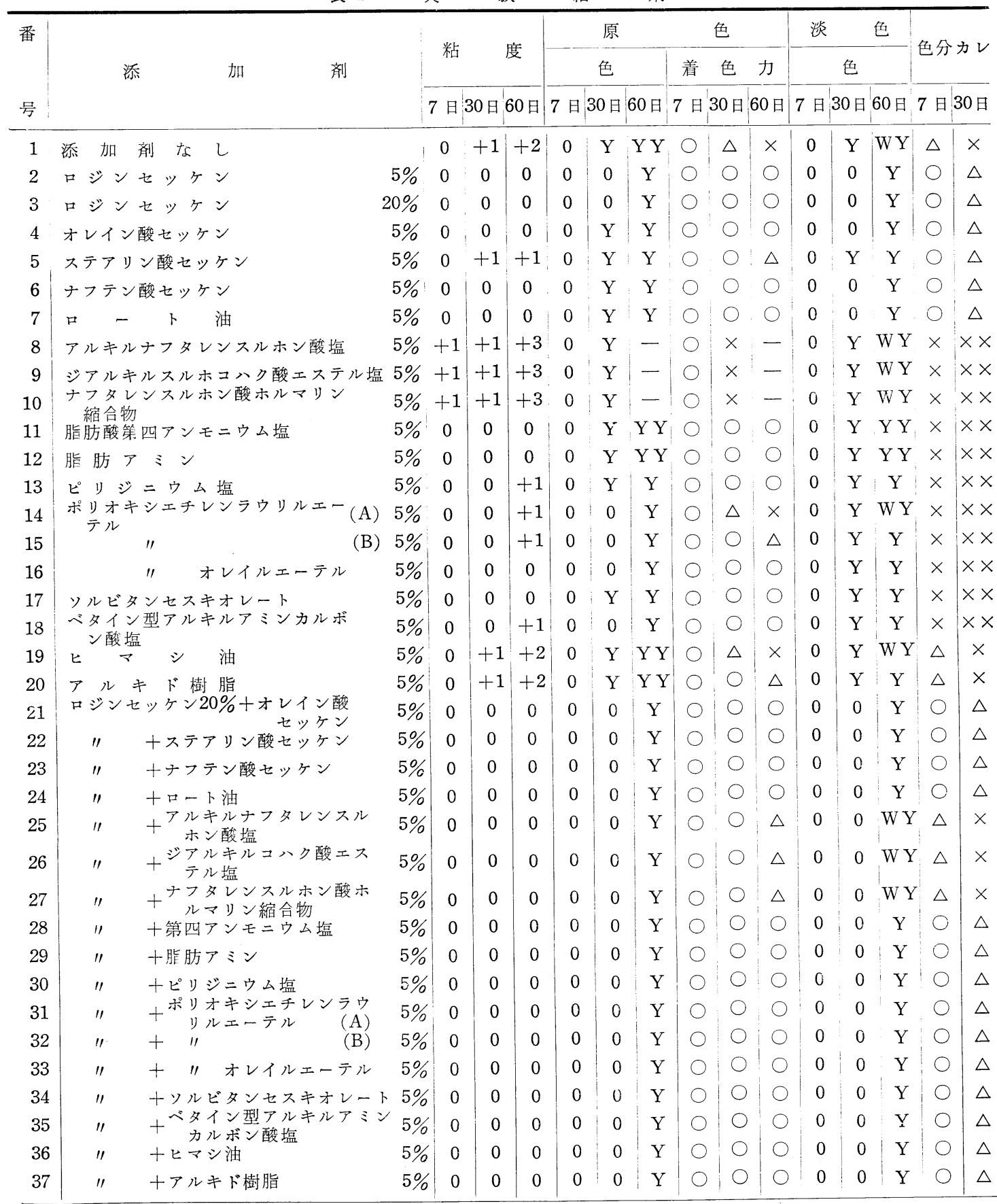


したものを $\mathrm{Y}$ ，白味を増したものをW とした。

iii) 着色力

貯蔵前後の原色塗料を一定量とり，10 倍量の白塗料で うすめた淡色塗料をつくり，その着色力の大小を比較・ 判定した。ほとんど変化しないものを○，少し低下した ものを $\Delta$, 低下の大きいものを $\times$ とした。

iv）色分カレ

淡色塗料を試験管にとり密封して静置し，色の分離状 態を観察した。わずかに変化したものを○，やや分離し たものを $\triangle$ ，かなり色分カレしたものを $\times$ ，著しいも のを メメとした。

v）顔料の凝集

貯蔵叙料を供試の樹脂ワニスをたは希 釈溶剤で約 20 倍にうすめ，乾燥することなく光学顕微鏡 (320 倍)で 検鏡した。

\section{2. 実 験 結 果}

実験結果は表 1 の特りである。

\section{3. 考察}

1. 貯蔵 1 週間ではいずれもほとんど変化なく, 約 1 カ月で変化が明りょうに現われた。

No. 1 原色塗 料
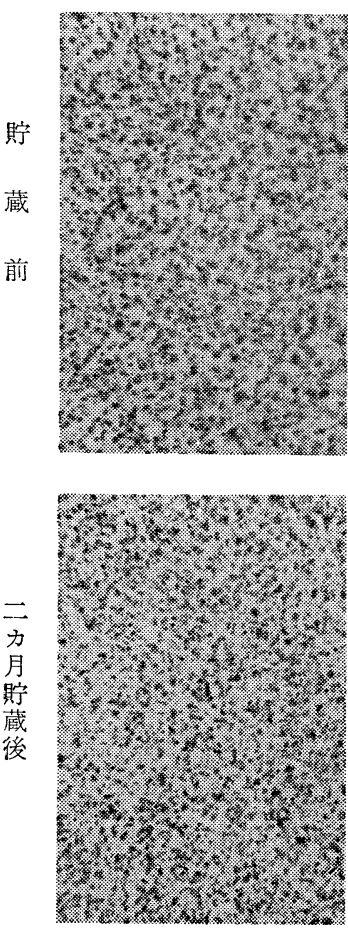

No. 2 原色塗 料
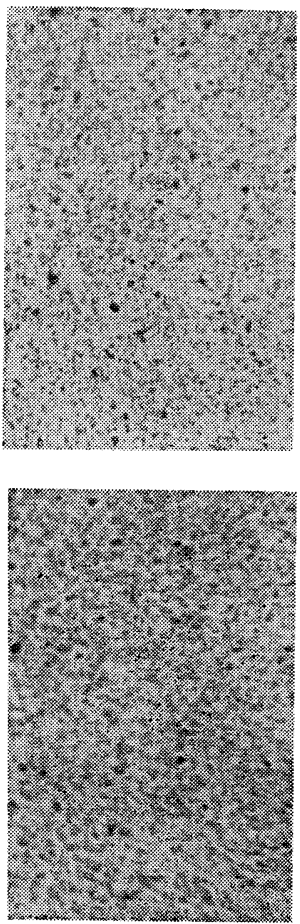

2. 添加剂を加えない顔料の場合，塗料貯蔵中に原 色・淡色ともに黄味を増し, 着色力を減少し, 色分カレ を起し，粘度を増大する。この変化は貯蔵 1 カ月でかな り明らかに認められ，2 カ月で顕著である。

3.レーキ化するときに金属セッケン共沈せしめた 場合，キジンセッケンは上記の粘度増加を防ぎ，色分カ レを少なくし，原色・淡色の色㧊よび着色力の変化を少 なくする効果がある。またオンイン酸セッケン，ナフテ ン酸セッケン款よびロート油はロジンセッケンと同様の 傾向があるが，その効果はやや少ない。ステアリン酸セ ッケンは効果がさらに少ない。

4.レーキ化後表面活性剤を添加した場合，アニオン 系表面活性剤は粘度增加, 着色力の低下, 色分カレを助 長する。ぬたカチオン系表面活性剤はいずれも粘度およ び着色力の変化を少なくするが, 色分カレを助長する傾 向が女る。このうちピリジニウム系は粘度増加を防が ず，色変化を少なくする。ノニオン系表面活性剤は色変 化を少なくし，色分カレを助長する。そして親油性のも のは粘度増加を防ぐ効果がある。ベタイン型アニオン・ カチオン両性表面活性剤は粘度・色・着色力の変化を少 なくするが，色分カレを助長し，カチオン系表面活性剈 にその傾向が強い。
No. 1 淡色塗 料
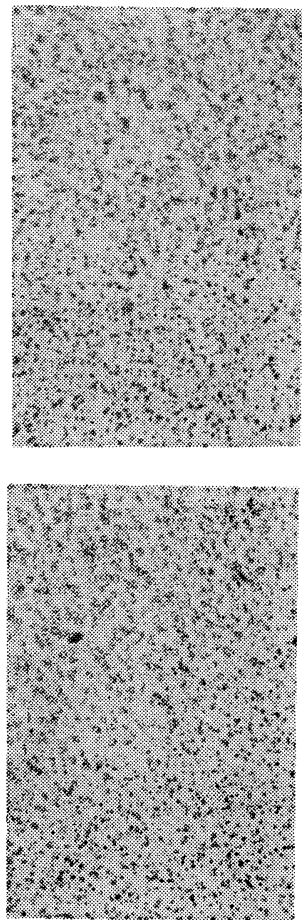

No. 2 淡色塗 料
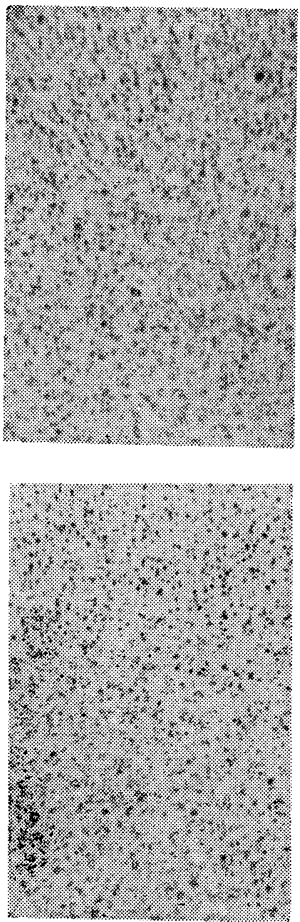

図 1 塗料中の顔 料 分散 状態 (320 倍) 

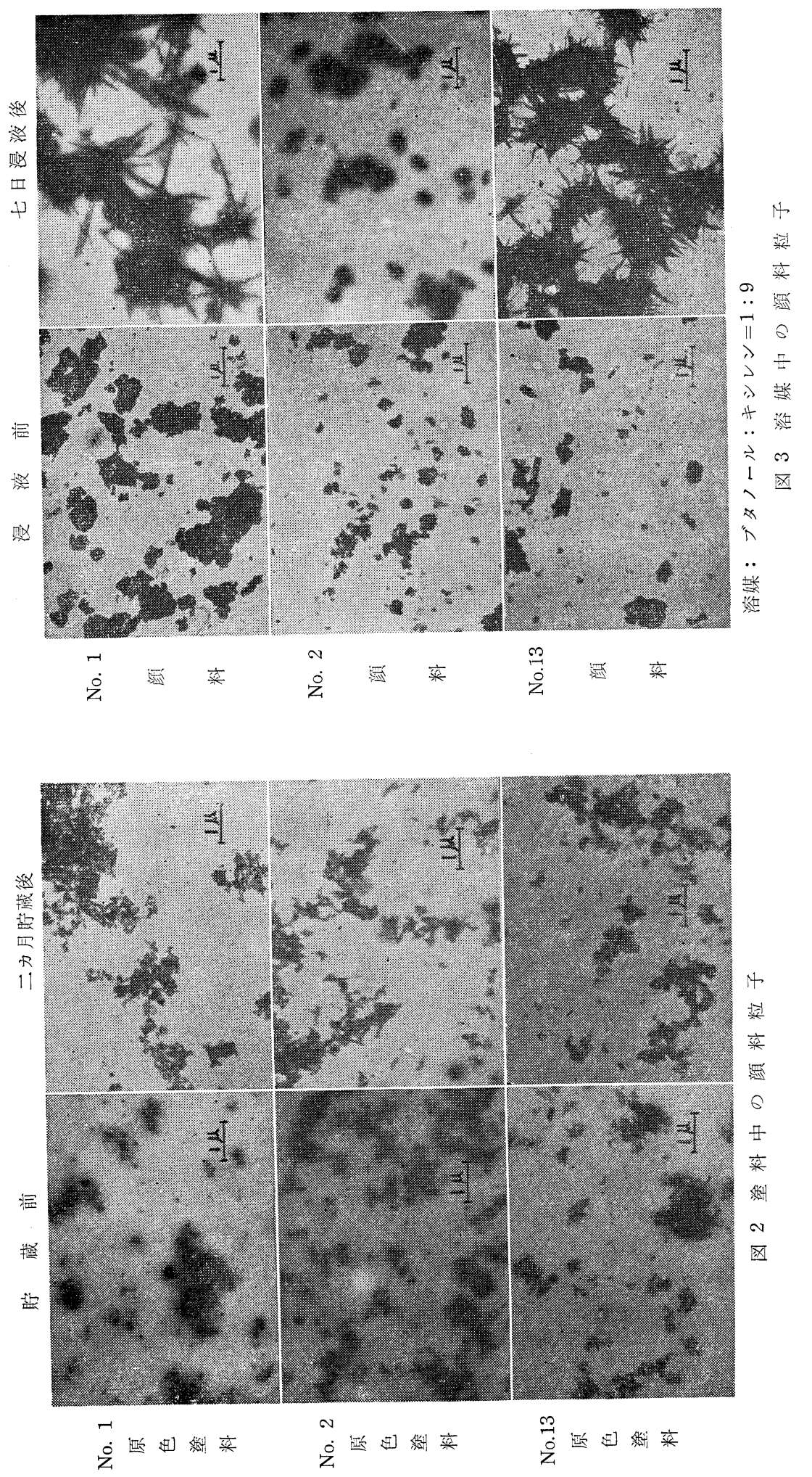
5. ヒマシ油変性アルキド樹脂は色执よび着色力の変 化を幾分防ぐ程度で効果が少なく，ヒマシ油はほとんど 影響を与えない。

6. ロジンセッケンに他のセッケン拈よび表面活性 剤, 樹脂などを併用した場合, その効果はほとんどロジ ンセッケンに支配されロジンセッケンのみの場合と抒拉 むね同じである。ただし，アニオン系表面活性剤併用の 場合にのみ, その影響が出て, 着色力の低下と色分カレ を防ぐロジンセッケンの効果を減殺する。

7. 貯蔵前後の塗料中の顔料分散状態を光学顕 微鏡 (320 倍) で検鏡した結果, いずれの原色塗料および淡 色塗料に和いてもパーマネントレッド $2 \mathrm{~B} \mathrm{Mn} レ$ レーの 分散粒子は凝集していないことがわかった。図1にとの 分散状態を例示する。これによると塗料貯蔵中の変化, すなわち粘度・色・着色力の変化, 色分カレなどは分散 顔料粒子の再凝集によるものではない。

8. 貯蔵前後の顔料の結晶形を電子顕微鏡により観察 した結果, 図 2 に示すよ 5 に, 塗料貯蔵 ( 2 力月) 中顔 料の結晶形にわずかな変化を認めたものもあるが，この 結晶形の変化と色・着色力などとの関連性についてはさ らに研究を要することであり，ここでは論及しない。し かし顔料をブタノール：キシレン=1:9 の混合液に浸 すと, 図 3 に例示するように数日以内にすでに結晶形が 変化したものがある。たとえば無添加剤顔料，ノニオン 系・カチオン系表面活性剤添加顔料などは結晶の生長を 起し, ロジンセッケン添加のものはほとんど結晶変化を みない。ビヒクル共存のため塗料中に㧅ては,この結
晶生長は阻止されるようである。

9. 貯蔵中に打ける色の変化括よび原色塗料の着色力 の変化, 粘度上昇, 色分カレなどのそれぞれの間には明 らかな関連性は見出せない。

\section{4. 結 論}

パーマネントレッド $2 \mathrm{~B}$ Mn レーキで着色したメラミ ン塗料の貯蔵性を検討した結果, 実験に用いた $2 \mathrm{~B} \mathrm{Mnレ}$ 一キに和いて, 添加剤がないものは貯蔵塗料の原色・淡 色の色, 原色塗料の着色力执よび粘度が明らかに変化し また，色分カレを起す。この場合レーキ化するときにロ ジン金属セッケンを共沈させると, 変化はかなり防がれ, 塗料の貯蔵性安定化に有効に働く。またオンイン酸セッ ケン・ナフテン酸セッケン・ロート油も幾分この効果が ある。このロジン金属セッケンにアニオン系以外の表面 活性剂を併用しても, ロジン金属セッケンの効果が大き く響き，ロジン金属セッケンのみの場合と同様な結果を 与え, 相乗効果はない。表面活性剂の添加はアニオン, カチオン，ノニオン系に分けそれぞれやや共通な結果を 示す点もあるが，その効果・影響は各表面活性剤につい て異なり，特に貯蔵性全般に有効なものはない。アルキ ド樹脂, ヒマシ油のエマルション添加も有効でない。

貯蔵中の粘度・色・着色力・色分カレなどの変化は塗 料中に分散した顔料粒子の再凝集によるものでない。ま た色，原色塗料の着色力の変化，粘度上昇，色分カレな どそれぞれの間には関連性は見出せなかった。

（昭 35.11 .9 関西支部秋季研究発表会において講演）

\section{学会ニュース}

535

537.2

第 8 回応用物理学関係連合講演会 $\quad 1961-3-31 \sim 4-2$ 早稲田大学で。色材関係題目は次のと和り。

2a II 4. 汗い光色彩計の試作と応用 谷水 護郎

2a II 5. 塗料の近赤外反射率 江森 康文

2a II 6. 自動分光測色装置

森礼於ら 2a II 7. 印刷用平滑度計に関する考察

2a II 8. 交照帰零式球面光沢計

$2 \mathrm{a} I I 9$. 織物の光沢に関する研究

$1 \mathrm{p}$ VII 5 . 静電気発生機構

1p VII 6. 石油系液体の帯電 $(\mathrm{N})$

1p UII 7. 流体輸送に伴 5 静電気

筒井 俊正 5

久保 盛唯ら

沢路 雅夫

葛西 昭成ら 大滝善太郎ら

1p UI 8. 静電気による液体の微粒化 檜 田元ら 萩原 正夫

(H-S) 